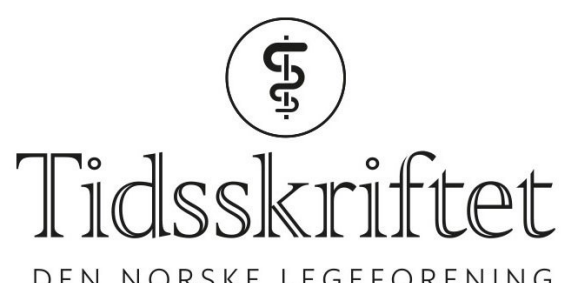

DEN NORSKE LEGEFORENING

\title{
D. Bratlid svarer
}

KOMMENTAR

\section{DAG BRATLID}

E-post: dag.bratlid@medisin.uio.no Dag Bratlid er spesialist i barnesykdommer, tidligere professor fra Norges teknisk-naturvitenskapelige universitet og tidligere overlege i nyfødtmedisin ved Barne- og ungdomsklinikken, St. Olavs hospital. Han har en mastergrad i helseadministrasjon og er tilknyttet Avdeling for helseledelse og helseøkonomi ved Institutt for helse og samfunn, Universitetet i Oslo. Ingen oppgitte interessekonflikter.

Flo har selvfølgelig rett i at antall liggedøgn ikke er det eneste mål på det legearbeid som en inneliggende pasient medfører, innskrivings- og utskrivingsprosessen er antagelig relativt lik for en pasient med et kort opphold som for en pasient med et langvarig opphold. Det er likevel ikke slik at det ikke foregår noe legearbeid hver av de fem dagene hennes eksempelpasient lå inne mellom innskriving og utskriving. Blant annet av denne grunn er det oftest vesentlig mer arbeid med utskriving (og epikrise) for en pasient som har ligget lenge enn en som så vidt har vært innom.

Hensikten med å bruke liggedøgn som et mål på mengden pasientarbeid i sykehusene, var imidlertid å beskrive utviklingen av forholdet mellom antallet leger og pasienter i norske sykehus, blant annet som bakgrunn for Rosta og Aaslands formulering om at «det snart er for mange (leger) om beinet». Dette er dagens situasjon, men som svært mange både leger og byråkrater ikke synes å ha fått med seg. Det medfører dessverre at man heller ikke forstår at legenes arbeidstidsordninger bør endres, slik at denne ressursen i enda større grad kan komme pasientene til gode.

Publisert: 16. februar 2018. Tidsskr Nor Legeforen. DOI: 10.4045/tidsskr.18.0112

(C) Tidsskrift for Den norske legeforening 2020. Lastet ned fra tidsskriftet.no 